LAUNCHING SPACE OBJECTS:

ISSUES OF LIABILITY AND FUTURE PROSPECTS 


\section{SPACE REGULATIONS LIBRARY}

\section{VOLUME 1}

\section{EDITORIAL BOARD}

Managing Editor

PROF. R. JAKHU, Institute of Air and Space Law, McGill University, Montreal, Canada

\section{MEMBERS}

M. DAVIS, Ward \& Partners, Adelaide, Australia

S. LE GOUEFF, Le Goueff Law Office, Luxembourg

P. NESGOS, Milbank, Tweed, Hadley \& McCloy, New York, U.S.A.

S. MOSTESHAR, Chambers of Sa'id Mosteshar, London, U.K. \&

Mosteshar Mackenzie, California, U.S.A.

L. I. TENNEN, Law Offices of Sterns and Tennen, Phoenix, Arizona, U.S.A. 


\title{
LAUNCHING SPACE OBJECTS: ISSUES OF LIABILITY AND FUTURE PROSPECTS
}

\author{
by
}

VALÉRIE KAYSER

KLUWER ACADEMIC PUBLISHERS

NEW YORK, BOSTON, DORDRECHT, LONDON, MOSCOW 
eBook ISBN: $\quad 0-306-48405-6$

Print ISBN: $\quad$ 1-4020-0061-8

(C)2004 Kluwer Academic Publishers

New York, Boston, Dordrecht, London, Moscow

Print (C2001 Kluwer Academic Publishers

Dordrecht

All rights reserved

No part of this eBook may be reproduced or transmitted in any form or by any means, electronic, mechanical, recording, or otherwise, without written consent from the Publisher

Created in the United States of America

Visit Kluwer Online at:

http://kluweronline.com

and Kluwer's eBookstore at:

http://ebooks.kluweronline.com 


\section{Table of Contents}

Chapter 1: Aims and Context 1

1.1 Overall Approach 2

1.2 Risk in Launching Space Objects, An Overview 3

1.2.1 What Type of Risk?

$\begin{array}{lll}1.2 .2 & \text { Risk Location } & 7\end{array}$

1.2.3 Communities Exposed 7

1.3 Approaches to Risk 8

1.3.1 The Engineer's Approach 9

1.3.2 The Legal Counsil's Approach 11

1.3.3 The Insurer's Approach 12

1.4 Liability Risk Management: Looking to the Future 14

Annex 1. Summary of Main Types of Space Insurance 17

\section{PART I: THE LABRYNTH OF DAEDALUS}

Chapter 2: The International Legal Framework 23

2.1 Space Treaties and Resolutions 24

2.1.1 Main Principles of Space Law: the context 25

(i) Principle of freedom of exploration and use 25

(ii) Principle of non-appropriation 26

(iii) Principle of applicability of international law 28

(iv) Restriction on military activities 29

(v) Responsibility and liability 29

(vi) Common interest and common heritage principles 29

(vii) International cooperation 30

2.1.2 Responsibility and Liability in Space Law 31

(i) Entities subject to responsibility/liability 33 States 33

International organizations $\quad 37$

Non-governmental entities $\quad 40$

(ii) The compensable damage 44

(iii) Type of liability 50

(iv) Potential claimants 51

(v) Procedure for claiming compensation 53

2.2 Examples of International Practice 58

2.2.1 Definition of Objects and Link to a State or Organization 59

2.2.2 Reference to the Liability Convention 60

2.2.3 Liability Between the Parties 62

Annex 1. Summary Tables on the Space Treaties 67 
3.1 Legal Framework for Launch Services in the United States 77

3.1.1 Evolution Towards the Development of a Concise Regulatory Framework

(i) Authority of US Government Agencies 79

(ii) Practical consequences of the multitude of Agencies

3.1.2 Initial Steps Towards Improvement of the Regulatory Framework for Launches

3.1.3 The First Regulatory Steps Put to the Test

3.1.4 The Consolidation Phase: the Commercial Space Launch Act (CSLA) and the Associated Regulatory Framework

(i) The Commercial Space Launch Act 91

(ii) When is a license required? 96

(iii) The licensing procedure 98

3.1.5 Liability and Insurance Issues 114

(i) Liability and insurance under the CSLA 114

(ii) The situation of private launch operators 118

(iii) The CLSA Amendments 122

(iv) Final Rule Concerning Financial Responsibility Requirements for Licensed Launch Activities

(v) Final Rule Effective 21 June 1999 for Codification of 14 CFR

3.2 European Legal Framework: The Ariane Launch Services 134

3.2.1 French Approach to Space Legislation 134

3.2.2 Overall Legal Framework for the Ariane Launch Services

(i) The initial phases of the program 136

(ii) The commercialization phase 137

3.2.3 Institutional Aspects of the Legal Control Exercised Over Arianespace

(i) Control via shareholding in the capital of Arianespace 138

(ii) The role of ESA 139

3.2.4 Liability for Ariane Activities 140

(i) Liabilities related to property of ESA
and the participants

(ii) Third party liability 142

(iii) Contractual allocations $\quad 143$ 
Chapter 4: General Rules of Common Law and Civil Law Susceptible of Governing Liability for Launch Services

4.1 Common Law: General US Law Applicable to Liability for Launch Activities

4.1.1 Contract Liability

(i) Liability for breach of contract

(ii) Warranties

(iii) Rules of contract interpretation

4.1.2 Tort Liability

(i) Negligence 156

(ii) Strict liability 161

4.1.3 Classical Means of Defense 168

(i) Defenses related to behavior or characteristics of the victim

(ii) Defenses related to limitation of the scope of the liability

(iii) Defenses related to time 175

4.1.4 Cumulation of Contract and Tort Claims 176

4.1.5 Vicarious Liability 177

4.1.6 Recoverable Damages 178

(i) Recoverable damages in general 178

(ii) Punitive damages 180

(iii) Liquidated damages, penalty clauses $\quad 181$

4.1.7 Force Majeure 182

4.1.8 Judicial Procedure Aspects 182

4.1.9 A brief overview of US case law related to space activities

(i) Berg v. Reaction Motors Division $\quad 186$

(ii) Smith v. Lockheed Propulsion 187

(iii) Pigott v. Boeing 187

(iv) Smith v. USA and Smith v. Morton Thiokol 187

(v) Lexington Insurance v. McDonnell Douglas 187

(vi) Appalachian Insurance v. McDonnell Douglas $\quad 188$

(vii) Martin Marietta v. Intelsat 189

(viii) Hughes Communication Galaxy v. USA 192

(ix) American Satellite Co. v. USA 193

(x) Lloyds of London v. McDonnell Douglas 193

4.2 Civil Law: The Example of French Law 194

4.2.1 Contract Liability 195

(i) Liability for breach of contract 196

(ii) Warranty 202

(iii) Rules of contracts interpretation 204 
4.2.2 Tort Liability

(i) Provisions of the Civil Code: liability for fault and strict liability

(ii) Product liability 214

4.2.3 Classical Means of Defense 217

(i) Defenses related to the behavior of the victim 217

(ii) Defenses related to the limitation of the scope of liability

(iii) Defenses related to time 225

(iv) Defenses available under the new product liability law

4.2.4 Cumulation of Contracts and Torts Claims 228

4.2.5 Vicarious Liability 230

(i) Specific types of liability for others 230

(ii) Towards a general principle of liability for others established by jurisprudence 233

4.2.6 Recoverable Damages 234

(i) Recoverable damages in general 234

(ii) Punitive damages 236

(iii) Liquidated damages, penalty clauses 236

4.2.7 Force Majeure 237

(i) Source in contracts and in torts 237

(ii) Criteria to be met by force majeure events 238

(iii) Effects of the force majeure 239

(iv) Force majeure clauses 240

4.2.8 Judicial Procedure Issues 240

4.2 Practice in Spacecraft Development Contracts:
The European Space Agency

4.3.1 Applicable Law 244

4.3.2 Performance by Contractors and
Control of Performance

4.3.3 Liability Provisions in the Contract 246

(i) Liability of the Contractor concerning equipment, supplies and technical documents made available by the Agency 246

(ii) Liability of the Contractor for damage caused to persons, goods or property 246

(iii) Liability of the Contractor for infringments of the law and third-party rights 247

(iv) Liability of the Contractor for performance of his subcontractors 247

(v) Res perit domo 248 
4.3.4 Limitation of Liability 248

4.3.5 Penalty Clauses 248

4.3.6 Warranty and Product Liability 249

4.3.7 International Space Station Provisions 252

4.3.8 Liability of the Contractor in case of serious Breach of Contract 253

4.3.9 Settlements of Disputes 253

\section{PART II.- ESCAPING THE LABYRINTH}

\section{Chapter 5: Issues in Liability Risk Management and}

\section{Proposals De Lege Ferenda}

5.1 An appraisal of the Legal Situation 258

5.1.1 A multitude of points of contact and an unadapted international legal environment

5.1.2 The Development of a Lex Mercatoria in the field of Launch Services

5.2 Methodology for our Further Discussions

5.3 Harmonizing the Practice of Inter-Participant

Waivers of Liability

5.3.1 The Limitations of Inter-Participants

Waivers of Liability

(i) Their validity is controversial in certain legal systems

(ii) Their validity may be contested in the absence of express acceptance 266

(iii) They cannot exclude wilful misconduct and gross negligence

(iv) They cannot exclude claims from individuals for bodily injury

(v) They do not always deal clearly and consistently with consequential damages 268

(vi) They are assessed in relation to the balance of the contract 268

(vii) Their interpretation is strict 269

(viii) Third-party liability allocations 269

(ix) The relationship between inter-participant waivers of liability and product liability $\quad 270$

(x) Flow down requirements 273 
5.3.2 Moving Forward with Inter-participant

Waivers of Liability

(i) Harmonization of inter-participant waivers of liability

(ii) Clarification of the essential obligations of the launch provider and launch customers $\quad 280$

(iii) The validation of the inter-party waivers in the public order of States

5.4 The International Law Framework

5.4.1 The Outer Space Treaty and the Liability Convention

(i) The current political atmosphere 285

(ii) Should we patch or should we review? 287

(iii) The need for addressing liability issues related to the launch of space objects $\quad 288$

5.4.2 Issues and Proposals 292

(i) The launching state: definition 292

(ii) Liability of the launching State 297

(iii) Appropriate State 297

(iv) Establishing the liability of the operator and legal channeling with respect to claims by third-parties 298

(v) Licensing requirements 300

(vi) Actions in recourse between States $\quad 300$

5.4.3 The Registration Convention 301

(i) Shortcomings of the Registration Convention 301

(ii) Proposals for an efficient registration system to improve the security of determination of the launching State

5.4.4 Conclusions on International Law Proposals 304

Chapter 6: Some Concrete Proposals 307

6.1 -Harmonization of Inter-Participant Waivers of Liability 307

Inter-Participants Liability Covenants in States

with Licensing Requirements (US Model)

-Inter-Participants Liability Covenants for States

without Licensing Requirements 325

6.2 Implementation Arrangements for the Space Treaties 335

Proposed Protocol 336

$\begin{array}{ll}\text { CONCLUSIONS } & 347\end{array}$

BIBLIOGRAPHY 351 